\author{
ks. Adam Kalbarczyk ${ }^{1}$ \\ Uniwersytet im. Adama Mickiewicza w Poznaniu
}

\title{
„Nie odtrącaj mnie w starości" \\ O potrzebie profilowanego przepowiadania dla seniorów
}

Ludzie mówią: „Pan Bóg stworzył świat piękny i wspaniały, ale starość to $\mathrm{Mu}$ się nie udała" ${ }^{2}$. W słowach tych pobrzmiewają po trosze ironia, obawa, smutek, odraza, ale też i wyrzut skierowany pod adresem Stwórcy. Wyrazem tych uczuć jest zamieszczona w pierwszym członie tematu tego artykułu modlitwa Psalmisty o szczęśliwą starość: „Nie odtrącaj mnie w czasie starości; gdy siły ustaną, nie opuszczaj mnie!” (Ps 71, 9). Zaskakująca to prośba - zwłaszcza że cała Biblia zapewnia człowieka, że Bóg go nigdy - a więc także i „w starości, i wieku sędziwym” (Ps 71, 18) - nie opuszcza, nie odtrąca; długowieczność zaś postrzegana jest w niej jako

1 Adam Kalbarczyk, ur. w 1957 r., kapłan archidiecezji poznańskiej, dr hab. nauk teologicznych, adiunkt w Zakładzie Liturgiki i Homiletyki Wydziału Teologicznego Uniwersytetu im. Adama Mickiewicza w Poznaniu, gdzie od wielu lat wykłada homiletykę. Jest germanistą i tłumaczem (przełożył m.in. P. M. Zulehnera, Schronienie dla duszy, Poznań 2006), ma na swoim koncie kilka publikacji książkowych: Bóg nieco bliższy. Myśli na niedziele i święta [A], Poznań 2004; Gemeindegruppen als Lebensorte, Poznań 2005; Widok z sykomory. Myśli na niedziele i święta [C], Poznań 2007; Odnalezione drachmy. Myśli na niedziele i święta [B], Poznań 2011; Teatr animacji jako medium słowa Bożego. Studium teatrologiczno-homiletyczne, Poznań 2013; wiele artykułów z zakresu teologii pastoralnej i homiletyki oraz liczne szkice homilii i kazań drukowanych w polskich periodykach homiletycznych.

2 J. Pawłowska, Nie odtrącaj mnie w starości. Poradnik dla osób opiekujących się ludźmi w podeszłym wieku, Poznań 2002, s. 6. 
znak miłości, łaskawości i błogosławieństwa Bożego. Psalmista w gruncie rzeczy w to wierzy - mówi bowiem: „Ty, Boże mój, jesteś moją nadzieją, Panie, ufności moja od moich lat młodych!” (Ps 71, 5). Jego prośba zaś jest raczej zawierzeniem Bogu swojego lęku przed odtrąceniem przez człowieka.

Wzorując się na Bogu, który jest podporą i opiekunem człowieka od łona matki (por. Ps 71, 6) aż po „brzeg życia wiecznego” - jak to wyraził św. Jan XXIII - Kościół prowadzi duszpasterstwo seniorów, które pojmuje jako zorganizowaną działalność mającą na celu uświęcenie i zbawienie osób w podeszłym wieku. Misję tę wypełnia poprzez „głoszenie im słowa Bożego, sprawowanie sakramentów, posługę charytatywną, a także realizację zadań integracyjnych i społecznych"3. Najważniejszym miejscem tego duszpasterstwa jest wspólnota parafialna. To przede wszystkim w niej ludzie starsi powinni czuć się ,jak u siebie" i mieć możliwość spojrzenia na swoje życie, pytania, potrzeby i doświadczenia z perspektywy Ewangelii.

W większości parafii w Polsce ludzie starzy mają zapewnioną opiekę duszpasterską, niemniej codzienne doświadczenie pokazuje, że dość słabo rozwinięty, jeśli nie zaniedbany czy wręcz lekceważony, jest ten element duszpasterstwa seniorów, który wymienia się zazwyczaj na pierwszym miejscu: głoszenie słowa Bożego. Czyż wielu seniorów nie czuje się właśnie w tym względzie odtrąconymi?

Dlatego w niniejszym przedłożeniu pragnę przedstawić zagadnienie profilowanego parafialnego przepowiadania dla ludzi w podeszłym wieku. Uczynię to w trzech etapach: najpierw podejmę się uzasadnienia potrzeby takiego przepowiadania, odwołując się do homiletyki i teologii duszpasterstwa; następnie omówię jego formy, sytuacje i treści; na końcu zaś określę jego podstawowy motyw: życie. Profilowane przepowiadanie dla seniorów rozumiem jako specjalne - co do formy, języka i treści - głoszenie słowa Bożego ludziom w podeszłym wieku' ${ }^{4}$, ukierunkowane na nich, obejmujące ich swoim oddziaływaniem.

\footnotetext{
J. Ostrowski, W. Przygoda, Seniorów duszpasterstwo, [w:] Leksykon teologii pastoralnej, red. R. Kamiński, Lublin 2006, s. 789.

Wyrażenia: „ludzie w podeszłym wieku”, „ludzie w wieku senioralnym”, „ludzi starzy, starsi”, ,seniorzy” traktuję ogólnie, choć w literaturze fachowej wyróżnia się w odniesieniu do ludzi starych trzy grupy wiekowe: wiek podeszły, starczy i sędziwy.
} 


\section{Dlaczego profilowane przepowiadanie dla seniorów?}

Przejdźmy zatem do uzasadnienia tezy o potrzebie profilowanego przepowiadania dla seniorów. Spojrzę na tę kwestię najpierw z perspektywy homiletycznej, a następnie duszpasterskiej.

\subsection{Uzasadnienie homiletyczne}

Jest rzeczą oczywistą, że pierwszorzędną misją Kościoła jest „przekazywać słowo Boże wszystkim ludziom, we wszystkich czasach i we wszyst-

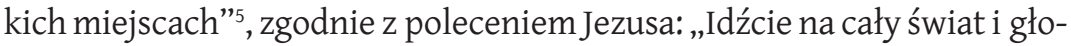
ście Ewangelię wszelkiemu stworzeniu" (Mk 16,15). Słowo tejże Ewangelii jest, jak uczy apostoł Paweł, „,mocą Bożą ku zbawieniu dla każdego wierzącego" (Rz 1, 16). Ponadto Kościół jest wspólnotą, w której wszyscy ludzie zostali powołani do wspólnego przeżywania i realizacji Bożego zamysłu miłości. Użyte w tych zdaniach sformułowania „wszyscy”, „wszystkim ludziom”, ,we wszystkich czasach”, ,wszelkiemu stworzeniu”, „dla każdego wierzącego" nie pozostawiają wątpliwości: słowo Boże winno być głoszone w s zy s t ki m ludziom, w każdym czasie, w każdej sytuacji, na każdym etapie ich życia. Sformułowania te nie sugerują jednak jednolitości wśród słuchaczy słowa Bożego; są oni bowiem pod wieloma względami zróżnicowani, a kaznodziejstwo, chcąc dotrzeć z Ewangelią do nich wszystkich, musi te różnice dostrzegać i uwzględniać w kazaniach specjalnych, skierowanych do poszczególnych grup wiekowych, stanów, płci czy zawodów ${ }^{6}$. Jeżeli zatem widzimy potrzebę profilowanego przepowiadania do dzieci, do młodzieży czy do dorosłych, to nie możemy nie zauważać jej w odniesieniu do ludzi starych. Kaznodzieja nie może przypominać sobie o najstarszych słuchaczach tylko przy okazji Światowego Dnia Chorego (11 lutego), rekolekcji parafialnych czy wizytacji biskupiej. Ludzie starsi potrzebują również, a może w szczególności, owej „mocy

5 Synod Biskupów XII Zwyczajne Zgromadzenie Ogólne Synodu Biskupów. Słowo Boże wżyciu i misji Kościoła. Lineamenta (25.03.2007), art. 13.

6 Zob. A. Lewek, Wspótczesna odnowa kaznodziejstwa. Zarys homiletykiogólnej, z. 2, Warszawa 1980, s. 106. 
Bożej ku zbawieniu". Dlatego trzeba ich uwzględnić nie tylko w kaznodziejstwie ogólnym, lecz przede wszystkim w specjalnym.

\subsection{Uzasadnienie teologicznopastoralne}

Potrzebę taką tłumaczą też względy duszpasterskie. Według nauczania Kościoła duszpasterze powinni pomóc osobom starym realizować swoje powołanie w Kościele i świecie, tak aby nie pojmowali swojej starości jako „dożywania” życia do końca czy biernego oczekiwania na śmierć, lecz jako naturalny etap życia, jako czas wartościowy, który należy i można przeżywać w postawie zaufania Bogu, okres „,pogłębienia życia duchowego przez usilniejszą modlitwę i gorliwą służbę braciom w miłości"7. Specjalne kaznodziejstwo dla seniorów jest jednym z istotnych przejawów takiej duszpasterskiej troski. Wokół nauczającego Jezusa gromadziły się tłumy, wśród których zapewne nie brakowało osób starszych, On zaś interesował się ich niedolą, przywracając im nie tylko zdrowie ciała, lecz przede wszystkim moc ducha. Kościół apostolski ściśle łączył posługę głoszenia słowa Bożego z troską także o ludzi starszych, często chorych, samotnych i bez środków do życia (zob. 1 Tm 5, 1-16; Dz 6, 1-6).

Uwzględnienie ludzi starych w przepowiadaniu specjalnym integruje ich z parafią, daje im poczucie przynależności do Kościoła i uczestniczenia w jego życiu, pomaga włączyć ich w dzieło apostolstwa, działalność charytatywną, apostolat w rodzinach, posługę liturgiczną i obronę życia od poczęcia do naturalnej śmierci; pomaga zrozumieć znaczenie praktyk religijnych, jak również uczy wspierania Kościoła swoim cierpieniem i modlitwą. Im samym zaś pomaga w pogłębieniu życia duchowego, sakramentalnego, wiary w Boga w kontekście przemijalności życia, w zrozumieniu spraw bieżących w perspektywie całego życia, w przyjmowaniu odpowiedzialności za innych i opieraniu relacji międzyludzkich na wierze i Ewangelii ${ }^{9}$.

Jan Paweł II, list Do moich Braci i Sióstr - ludzi w podeszłym wieku [dalej: LdS], 16.

Zob. Jan Paweł II, list Novo millenio inneunte, 51; LdS 9.

Zob. J. Ostrowski, W. Przygoda, Seniorów duszpasterstwo, dz. cyt., s. 791-792; J. Müller, Pastoraltheologie. Ein Handbuch für Studium und Seelsorge, Graz-Wien-Köln 1993, s. 149-157. 
Ważnym argumentem za potrzebą wprowadzania i rozwijania profilowanego przepowiadania dla seniorów są też współczesne uwarunkowania socjologiczne. W nowoczesnych społeczeństwach - w wyniku rozwoju medycyny, polepszenia warunków życia - przybywa stale ludzi starych, a w rezultacie zmian w strukturze rodziny i innych zjawisk, takich jak np. wszechobecny kult młodości, ludzie starzy są często osamotnieni, zepchnięci na margines społeczeństwa i życia ${ }^{10}$.

\section{Formy, sytuacje i treści przepowiadania dla seniorów}

Ażeby ubogacać słowem Bożym wiarę ludzi w podeszłym wieku, podsycać ich nadzieję i dawać pokarm dla ich pobożności, należy stosować przede wszystkim tradycyjne, sprawdzone i znane im formy przepowiadania ${ }^{11}$. Ludzie starzy na ogół nie lubią zmian i innowacji w swoim otoczeniu; wolą pozostać przy tym, co znają, i wiedzą, jak należy z tym postępować. Nie wyklucza to jednak roztropnego stosowania innych, nowych form głoszenia słowa Bożego, jak np. świadectwa czy homilie dialogowane.

Pośród tych tradycyjnych form przepowiadania pierwsze miejsce zajmuje homilia. Co prawda każda homilia - czy to niedzielna, czy w dni powszednie - powinna stanowić „pokarm konieczny dla podtrzymania chrześcijańskiego życia"12 tak dla ludzi młodych, jak i starych, jednak szczególną rolę w formacji duchowej, również biblijnej, osób starszych może odegrać homilia w dni powszednie. Regularnie wygłaszana - choćby i krótka - stanowi niezwykle istotny element formowania słowem Bożym osób, które chcą i mogą być codziennie lub prawie codziennie na mszy świętej. Ponieważ w większości są to ludzie starsi (mam tu na myśli ogólnie ludzi w wieku senioralnym, na tyle sprawnych fizycznie, że mogą przychodzić samodzielnie lub z kimś do kościoła), homiliści powinni zadbać przede wszystkim o odpowiedni język przekazu ewange-

10 Zob. P. M. Zulehner, Pastoraltheologie. Übergänge. Pastoral zu den Lebenswenden, Bd. 3, Düsseldorf 1990, s. 85-111.

${ }_{11}$ Zob. Altenarbeit in der Diözese Rottenburg-Stuttgart. Materialdienst 29. Handreichungen für die Seelsorge, Rottenburg a. N. 1991, s. 22.

12 Ogólne wprowadzenie do Mszału rzymskiego [dalej: OWMR], 65. 
licznego, który odpowiadałby ich sytuacji, mentalności, doświadczeniom i problemom ${ }^{13}$. Tylko wtedy homilia spełni swoje zadanie, tzn. umieści c ałe życie i c ałe go człowieka, człowieka w podeszłym wieku, w nowym zbawczym świetle Ewangelii1 ${ }^{14}$. Ks. Wiesław Przygoda uważa, że w przepowiadaniu dla seniorów konieczne jest „przejście z metod dedukcyjnych na indukcyjne”, zaś „osadzenie treści wiary w doświadczeniu ludzi, do których jest skierowane słowo Boże, wzmacnia autorytet i społeczną wiarygodność Kościoła"15.

Posługiwanie się przystępnym dla ludzi starszych językiem i nawiązywanie w codziennych homiliach przynajmniej w jakiejś części do ich doświadczeń życiowych jest siłą rzeczy łatwiejsze dla starszego kapłana. Starsi słuchacze prawie na pewno będą go odbierać jako kogoś, kto idzie razem z nimi i tak samo jak oni znosi trudy drogi, kto dzieli ich doświadczenia, kto się z nimi solidaryzuje, a przede wszystkim ich rozumie. Nieocenioną wartość ma tu osobiste świadectwo życia kaznodziei. Przykładem takiego świadectwa są poruszające słowa Jana Pawła II z listu Do moich Braci i Sióstr - ludzi w podeszłym wieku z 1999 roku:

Sam posunięty w latach, odczuwam [...] potrzebę nawiązania dialogu z wami. Czynię
to, dziękując najpierw Bogu za dary i dobrodziejstwa, jakich udzielał mi obficie aż
do tej chwili. Przemierzam w pamięci kolejne etapy mojego życia, splecionego z hi-
storią większej części obecnego stulecia, i widzę wyłaniające się z przeszłości twa-
rze niezliczonych osób, w tym niektórych szczególnie mi drogich. Wiążą się z nimi
wspomnienia wydarzeń zwykłych i nadzwyczajnych, chwil radości i przeżyć nazna-
czonych cierpieniem. Ponad tym wszystkim jednak widzę opatrznościową i miło-
sierną dłoń Boga Ojca, który „najlepiej kieruje wszystkim, co istnieje” i „,wysłuchuje
[...] wszystkich naszych próśb zgodnych z Jego wolą” (1 J 5, 14). Do Niego zwracam
się słowami Psalmisty: „Boże, Ty mnie uczyłeś od mojej młodości, i do tej chwili
głoszę Twoje cuda. Leczi i w starości, i w wieku sędziwym nie opuszczaj mnie, Boże,
gdy [moc] Twego ramienia głosić będę, całemu przyszłemu pokoleniu - Twą po-
tęgę” (Ps 71 [70], 17-18). Myślą ogarniam też was, którzy „,przeżyliście już czasów
wiele” (por. Mdr 4,13), drodzy ludzie starzy wszystkich języków i kultur (LdS 1).

13 Zob. J. Ostrowski, W. Przygoda, Seniorów duszpasterstwo, dz. cyt., s. 792; W. Przygoda, Starych duszpasterstwo, [w:] Encyklopedia katolicka, t. 18, red. E. Gigilewicz, Lublin 2013, kol. 869.

${ }_{14}$ Zob. A. Kalbarczyk, Homilia-najwyższa forma przepowiadania w Kościele, [w:] Msza Święta-rozumieć, aby lepiej uczestniczyć. Wykład liturgii Mszy, red. J. Hadalski, Poznań 2013, s. 236 .

15 W. Przygoda, Formacja apostolska ludzi w podeszłym wieku, „Perspectiva” 1 (2009), s. $181-182$. 
Jednakże tak jak homilii do dzieci nie muszą głosić wyłącznie młodzi kapłani, tak samo głoszeniem homilii do osób starszych nie muszą zajmować się wyłącznie księża emeryci. Niemniej kiedy przed starszym audytorium staje młody kaznodzieja, po obu stronach może wytwarzać się pewne napięcie: księdza może przytłaczać świadomość, że jego stosunkowo mała jeszcze znajomość życia nie pozwala mu na to, by mówić tym, którzy „przeżyli już czasów wiele”, jak mają żyć; zaś słuchaczom może być trudno wyzbyć się uprzedzenia, które zawarte jest w pytaniu: „Co taki młody człowiek może wiedzieć o życiu i starości?”. Napięcie to znika jednak, gdy młodsi kaznodzieje są otwarci na ludzi starych i poprzez swoje codzienne duszpasterskie zaangażowanie starają się szczerze poznać blaski i cienie starości, jak też wsłuchiwać się w to, co ci ludzie mówią, i wczuwać się w to, co przeżywają. Nade wszystko jednak powinni głosić im słowo Boże w postawie szacunku - zgodnie ze słowami Pisma: „Przed siwizną wstaniesz, będziesz szanował oblicze starca, w ten sposób okażesz bojaźń Bożą" (Kpł 19, 32). Dowartościowanie w homiliach doświadczeń ludzi starych przez młodego kaznodzieję będzie wyrazem szczególnie potrzebnej w naszych czasach międzypokoleniowej solidarności. A ponieważ każda prawdziwa homilia opiera się na spotkaniu, dialogu, partnerstwie, zażyłej rozmowie, świadectwie, wymianie odczuć, doświadczeń i wiedzy, na dawaniu i braniu, to młodzi kaznodzieje powinni odnieść także i do siebie słowa Jana Pawła II z cytowanego wcześniej listu:

\footnotetext{
Wzywam was, młodzi przyjaciele, abyście traktowali [ludzi dojrzałych wiekiem] wielkodusznie i z miłością. Starsi potrafią dać wam znacznie więcej, niż możecie sobie wyobrazić. W Księdze Mądrości Syracha znajdujemy na ten temat takie pouczenia: „Nie odsuwaj od siebie opowiadania starców, albowiem i oni nauczyli się go od swoich ojców” $(8,9)$; „Stań na zgromadzeniu starszych: a [jeśli] kto jest mądry, przyłącz się do niego!” $(6,34)$, ponieważ „starcom przystoi mądrość" $(25,5)$ (LdS 12).
}

Z wezwaniem tym korespondują też słowa papieża Franciszka, który uważa, że młodym „wypada” słuchać starszych, gdyż wnoszą oni „pamięć i mądrość doświadczenia, która zachęca, by głupio nie powtarzać tych samych błędów z przeszłości”. Ale i starszym „wypada” słuchać młodych; oni bowiem wzywają do „rozbudzenia i pogłębienia nadziei, ponieważ 
noszą w sobie nowe tendencje ludzkości” i otwierają ich na przyszłość, aby „nie byli zakotwiczeni w nostalgii za strukturami i zwyczajami, które nie są już życiodajne w dzisiejszym świecie"16.

Codzienne homilie, ukierunkowane w całości lub częściowo na osoby starsze, powinny opierać się na biblijnych perykopach przeznaczonych na dany dzień i uwzględniać ich podstawowe zbawcze przesłanie. Jednakże w fazie motywacyjnej i aplikacyjnej mogą lub powinny zawierać odniesienia do konkretnych życiowych doświadczeń i duchowych potrzeb ludzi starszych, tak aby „mogli przyjąć usłyszane słowo i by wydało ono owoce"17. Dla ćwiczenia umysłu, tak potrzebnego w tym okresie życia człowieka, warto w fazie eksplikacyjnej pokusić się o jakieś drobne, istotne dla podjętego tematu objaśnienia egzegetyczne. $Z$ doświadczenia wiem, że starsi słuchacze cieszą się, gdy mogą się przy okazji dowiedzieć i nauczyć czegoś nowego. To dla nich także wyraźny sygnał, że traktuje się ich poważnie.

Okazją do zwracania się ze słowem Bożym do ludzi starych mogą być też homilie niedzielne, świąteczne - zwłaszcza gdy odczytywane wówczas perykopy biblijne same podsuwają temat starości (np. teksty o Elżbiecie i Zachariaszu czy Symeonie i Annie). Podejmowanie takiej tematyki na forum wspólnoty, którą tworzą ludzie w różnym wieku, może pomóc w budzeniu solidarności między pokoleniami, a nade wszystko uczyć szacunku i miłości do ludzi starych, którzy dzięki temu mogą czuć się - mimo słabnących sił - żywą częścią tej wspólnoty (por. LdS 12). Podobne możliwości dają homilie odpustowe i jubileuszowe (np. na złoty jubileusz małżeństwa czy kapłaństwa), a nawet pogrzebowe (świadectwo życia chrześcijańskiego zmarłej starszej osoby).

Także przy celebracji sakramentu namaszczenia chorych „należy poświęcić więcej czasu na celebrację Słowa”, by pomóc starym i często chorym ludziom w przeżywaniu z wiarą ograniczeń starości, a zwłaszcza swojego cierpienia, „w jedności z odkupieńczą ofiarą Chrystusa, który wyzwala nas od zła” (VD 61).

16 Franciszek, adhort. apost. Evangelii Gaudium, 108.

17 Benedykt, adhort. apost. Verbum Domini [dalej: VD], 59. 
Miejscem profilowanego przepowiadania dla seniorów może być też sakrament pokuty i pojednania. Do indywidualnej spowiedzi, np. w ramach dnia skupienia czy rekolekcji, warto przygotować osoby starsze przez przeznaczone tylko dla nich nabożeństwo pokutne z ułożonym pod kątem ich potrzeb rachunkiem sumienia, z odpowiednimi czytaniami, jak też stosowną homilią (zob. VD 61). Także konfesjonał jest miejscem formowania starszych penitentów słowem Bożym, które „oświeca wiernego do poznania swoich grzechów, wzywa go do nawrócenia i napełnia go ufnością w miłosierdzie Boże"18.

Wszystkie nabożeństwa ludowe (np. nabożeństwo majowe) stanowią również ważną przestrzeń, w której poprzez specjalne kazania można formować ludzi starszych, najliczniej - jak wiadomo - w nich uczestniczących. Szczególne znaczenie będą tu miały też kazania, konferencje czy rozważania na okolicznościowych nabożeństwach odprawianych dla seniorów (i ich rodzin) z okazji Dnia Babci i Dziadka, Wigilii, spotkania opłatkowego, Wielkanocy, jak też dni skupienia i pielgrzymek.

Specjalne konferencje dla ludzi starszych powinny być głoszone w trakcie rekolekcji parafialnych i misji świętych. W proponowanych zazwyczaj przez rekolekcjonistów i misjonarzy naukach stanowych dla mężczyzn i kobiet ludzie starsi rzadko niestety mogą znaleźć coś dla siebie.

Niezmiernie ważna jest też katecheza osób starszych w ramach katechezy dorosłych. Szczegółowe cele tej katechezy formułuje się następująco: ,podtrzymywanie sił fizycznych, uczuciowych, intelektualnych i duchowych; właściwe wykorzystanie czasu wolnego; rozumienie i zaakceptowanie ograniczeń wieku; wzrost w wierze; przygotowanie do śmierci; uczestnictwo w życiu wspólnoty chrześcijańskiej"19. Przede wszystkim jednak powinna być ona dostosowana do potrzeb tych osób. Jedną z nich może być skorygowanie niewłaściwego obrazu Boga, jaki często w sobie noszą.

18 Obrzędy Pokuty. Wprowadzenie teologiczne i pastoralne, 17.

19 Zob. K. Misiaczek, Osoba starsza w katechezie, www.opoka.org.pl/biblioteka/T/TA/ TAK/km_osoba_starsza.html [01.04.2014]; R. Ceglarek, Katecheza dla osób starszych, „Ateneum Kapłańskie" 1 (2011) t. 157, s. 61-72. 


\section{Podstawowy motyw przepowiadania dla seniorów: życie}

Jak mogliśmy się przekonać, jest bardzo wiele możliwości przepowiadania dla seniorów. Co jednak stanowi jego podstawowy motyw, który zbierałby w sobie ogromne bogactwo treści głoszonych tej grupie słuchaczy? Moim zdaniem w czasie, w którym dopełnia się miara ludzkiego życia, należy przepowiadać przede wszystkim życie, życie silniejsze niż śmierć, głosić życie niejako wbrew śmierci. Jak zatem mówić ludziom starym o życiu?

Paul M. Zulehner pisze:

Nasze życie na ziemi to „trzecia ciąża”, a śmierć to narodziny do życia, o którym się mówi „wieczne” lub po prostu „pełne”. Używa się przy tym obrazów nieba i raju, ale też i światłości wiekuistej czy wiecznego odpoczynku. Człowiek zawsze będzie na ziemi nieco obcy. Ma to nam przypominać, że nie zostaliśmy stworzeni (tylko) dla ziemi, lecz dla nieba. [...] Stąd też zasadniczym celem szerzenia religijnej sztuki życia było zawsze nie tylko budzenie miłości do ziemi, lecz także nabywanie umiejętności ciągłego otwierania się na niebo. Świadczy o tym stara mszalna kolekta: „Panie, naucz nas w zmienności tego świata wznosić nasze serca tam, gdzie są prawdziwe mądrości" (por. modlitwa dnia z 21 niedzieli okresu zwykłego) ${ }^{20}$.

Słowa słynnego wiedeńskiego teologa - zwłaszcza te o miłości do ziemi i umiejętności otwierania się na niebo - pokazują, że zawsze, a więc i w starości, trzeba mówić o życiu doczesnym i wiecznym i że należy mówić o nich łącznie, bez przeciwstawiania ich sobie, zachowując równowagę w poruszaniu jednego i drugiego tematu - jednakże zawsze z wyraźnym wskazaniem na życie wieczne jako cel naszego ziemskiego życia i jednocześnie pełnię życia. Kaznodzieja powinien być rzecznikiem, , adwokatem" jednego i drugiego życia. Nie może więc gloryfikować jednego i jednocześnie deprecjonować drugiego. Mówiąc o życiu doczesnym, nie powinien ograniczać się do jego negatywnych stron (choć z drugiej strony nie wolno mu ich też przemilczać!) i przedstawiać go wyłącznie jako „łez padołu”, „kary za grzechy”, czasu „zasługiwania” na niebo czy „poczekalni" do nieba. Nie wolno mu też posługiwać się życiem wiecznym,

${ }^{20}$ P. M. Zulehner, Schronienie dla duszy. Ćwiczenia duchowe dla niezbyt pobożnych, przeł. A. Kalbarczyk, Poznań 2006, s. 19-20. 
niebem jako tanią pociechą dla tych, którym się źle mają. Powinniśmy zatem mówić seniorom o życiu: o jego fragmentach i o jego pełni.

Żeby uniknąć tych i podobnych skrajności, trzeba o jednym i drugim życiu mówić biblijnie, w duchu Biblii. Ona zaś przedstawia życie zawsze - nawet w starości - jako dar, a Boga jako źródło i dawcę życia. Jest to co prawda dar kruchy, ale jednocześnie cenny i święty. Kto uważnie wczytuje się w tekst Pisma Świętego, zauważy, że obiecane nam przez Boga życie wieczne jest w nim opisane jako przekraczające wszelkie wyobrażenia wypełnienie naszych niepomiernych pragnień, a zwłaszcza tych trzech podstawowych: mieć imię (Bóg nie zapomni naszego imienia; kiedy przejdziemy przez bramy śmierci, On wezwie nas po imieniu, wskrzesi nas; nasze imiona odnajdziemy w Księdze Życia, zapisane na dłoni Boga, który nas stworzył po to, abyśmy żyli); mi eć władzę (Bóg zniesie na zawsze wszelkie ograniczenia naszej wolności, władzy i miłości; będziemy zasiadać na „tronach” i „panować”, tzn. będziemy wolni, niezależni, tworząc pełną miłości wspólnotę zbawionych; będzie to wielkie święto wyzwolenia; Bóg poskłada w całość kawałki, fragmenty naszego życia i je dopełni); mieć swoje miejsce, dom, ojczyznę (otrzymamy od Ojca przygotowane nam mieszkanie w niebie; Bóg będzie naszym domem, ojczyzną; nastanie nowe niebo i nowa ziemia, miasto nowe Jeruzalem, pośrodku którego zamieszka Bóg).

W kontekście tych trzech podstawowych pragnień, najgłębszych tęsknot człowieka należy też mówić mu o jego życiu doczesnym. Biblia wzywa nas, abyśmy korzystali przy tym z Jezusowej „wiedzy o życiu”, z Jego „doświadczeń życiowych”, z ich pomocą kształtowali i interpretowali nasze życie, abyśmy w Nim żyli: w Nim jest życie, On jest wypełnieniem obietnicy życia w obfitości, On jest „drogą, prawdą i życiem” (J 14, 6), On jest naszym życiem.

O życiu doczesnym i wiecznym należy mówić ludziom starszym także profetycznie. Oznacza to, że zawsze musimy sobie zadawać pytanie, czy nasze mówienie o jednym i drugim życiu jest rzeczywiście słowem Bożym. Przede wszystkim jednak znaczy to, że słowo Boże o życiu mamy głosić - wzorem starotestamentowych proroków, Jezusa-Proroka i Jego uczniów - nie okazjonalnie, lecz przy każdej okazji, „w porę i nie w porę”, w każdą porę, często wbrew światu, jako niewygodną prawdę, nierzad- 
ko narażając się na drwiny i szykany (por. Jer 20, 8). A we współczesnym świecie, który coraz bardziej gubi koncepcję bezwzględnej wartości człowieka i jego życia na rzecz pojmowania go jako swego rodzaju ,produktu” czy „przedmiotu” (często o niskiej wartości), którym można dowolnie manipulować, którego można się pozbyć (np. umieścić w domu starców czy poddać eutanazji), trzeba głosić z mocą i odwagą proroków słowo o życiu, które na każdym etapie jest od Boga i dla Boga.

Mówiąc zarówno o życiu doczesnym, jak i wiecznym, natrafiamy często na granice słowa i stajemy przed tym, co niewyrażalne. Dlatego szczególnie w tym względzie potrzebujemy kaznodziejów kompetentnych w dziedzinie mistagogii. Kaznodzieja mistagog głosi życie jako misterium, tajemnicę i uwypukla jego transcendentny wymiar. Wprowadza słuchaczy coraz głębiej w tę tajemnicę, opierając się przy tym na własnym doświadczeniu żywego Boga w swoim życiu. I tylko w ten sposób może pomóc swoim słuchaczom, zwłaszcza starym i schorowanym, odkryć i doświadczyć obecności żywego Boga w ich codziennym życiu. Tam, gdzie zawodzą go słowa, tam może się posługiwać symbolami i obrazami, w które obfituje liturgia Kościoła, będąca w gruncie rzeczy wielką, wspaniałą celebracją życia.

Jeśli chcemy głosić seniorom kazania o życiu doczesnym i wiecznym, to wcześniej czy później pojawi się w nich temat zależności naszego życia wiecznego od życia doczesnego, a wraz z nim także jego aspekt moralny - tak ważny dla osób, które mają świadomość rychłego stanięcia przed trybunałem Boga. Ważne jest, aby nie odzierać tego tematu z mistyki, gdyż wtedy nasze kazania będą pełne moralizujących, etycznych apeli i bezdusznego, budzącego lęk i lekceważącego naszą wolność prawa, które - jak mówi Paul M. Zulehner - ,jedynie pokazuje, że nie możemy żyć tak, jak byśmy tego chcieli”21. Tymczasem prawdziwa moralność zakłada otwarcie się całego człowieka na uzdrawiającą i przemieniającą moc Boga.

Kaznodzieja mówiący o życiu doczesnym i wiecznym musi się wczytywać niejako równolegle w dwa teksty: tekst Biblii i tekst, jaki pisze nasze codzienne życie. Jest rzecznikiem, ,adwokatem” tekstu biblijnego

${ }^{21}$ P. M. Zulehner, Wie Musik zur Trauer ist eine Rede zur falschen Zeit. Wider den kirchlichen Wort-Durchfall, Ostfildern 1998, s. 53 (tłum. A. Kalbarczyk). 
i życia codziennego słuchaczy. Jednemu i drugiemu winien jest rzetelność i uczciwość. Nie wolno mu przed słuchaczami zatajać pełnego życia przesłania tekstu biblijnego, a przed tekstem biblijnym pełni codziennego życia słuchaczy. Ma głosić słowa życia, ma pokazać słuchaczom, że przesłanie tekstu biblijnego ma konkretne odniesienia do ich życia, że mówi coś o ich życiu. Nie da się tego zrobić w oderwaniu od życia. Homilia, kazanie, nauka rekolekcyjna czy katecheza o życiu doczesnym i wiecznym muszą być - także w odniesieniu do osób starszych - głęboko osadzone w realiach naszego codziennego życia. Dlatego kaznodzieja musi je znać. Pozna je zaś jedynie poprzez swoje duszpasterskie zaangażowanie, swoją żywą troskę o życie owiec. Wówczas też i jego kazania o życiu doczesnym i wiecznym będą wyrazem jego duszpasterskiej troski o życie słuchaczy. Będzie mówił z troską o życie. Będzie mówił o życiu życiowo.

O podarowanym i obiecanym nam przez Boga życiu doczesnym i wiecznym należy mówić żywo, z zaangażowaniem, przekonaniem, z wiarą, radością, zachwytem i fascynacją, tak aby stale pobudzać u słuchaczy apetyt na życie, podtrzymywać w nich nadzieję na życie - zwłaszcza u tych, którzy mają już dość życia. Przede wszystkim zaś trzeba o nim mówić z miłością, co pięknie wyrażają słowa piosenki napisanej przez Wojciecha Młynarskiego i Włodzimierza Korcza, a śpiewanej przez Edytę Geppert Och, życie, kocham cię nad życie: „Kocham cię życie | Poznawać pragnę cię, pragnę cię | Pragnę cię w zachwycie | I spotkać człowieka, | Który tak życie kocha | I tak jak ja | Nadzieję ma...". Bez tego nasze mówienie o życiu zabrzmi w uszach naszych słuchaczy, szczególnie starszych słuchaczy, jak „muzyka w dzień żałoby” (Syr 22, 6) 22.

W gruncie rzeczy nasze zadanie nie polega wyłącznie na mówieniu. Bardziej niż słów o życiu ludzie starsi potrzebują dziś miejsc, przestrzeni życia, tzn. słów wprowadzonych w życie poprzez wspólnoty wierzących. Nie możemy być dla nich jedynie drogowskazami, które pokazują im dro-

22 Zob. A. Kalbarczyk, Jak mówić w kazaniach o życiu doczesnym i wiecznym? „Biblioteka Kaznodziejska" 6 (2008) 152, s. 29-33. 
gę, same zaś pozostają na skraju tej drogi. Mamy do końca towarzyszyć tym ludziom w ich życiowej drodze, w drodze ku życiu.

„Ty masz słowa życia wiecznego" $(\mathrm{J} 6,68)$ - powiedział Szymon Piotr do Jezusa. Powiedział tak nie dlatego, że Jezus wiele mówił o życiu wiecznym, lecz dlatego, że objawił mu się jako ktoś, kto jest po brzegi wypełniony życiem. „Nam wystarczyłoby, gdybyśmy w naszych Kościołach mieli choć śladowe ilości tego życia" - mówi Zulehner. Wtedy też z czystym sumieniem moglibyśmy o nim mówić ludziom, którzy zbliżają się do jego kresu - choćby tak, jak czynił to św. Jan Paweł II, który w 1998 roku tak zwrócił się do ludzi w podeszłym wieku:

Drodzy bracia i siostry, nie traćcie otuchy, życie nie kończy się na ziemi, ale przeciwnie - tylko się tutaj zaczyna. Musimy być świadkami zmartwychwstania! Człowiek stary powinien być pełen radości: spokojnej radości z tego, że czas się dopełnia i bliska jest nagroda, jaką Chrystus Pan przygotował swojemu wiernemu słudze. Przychodzą tu na myśl słowa apostoła Pawła: „W dobrych zawodach wystąpiłem, bieg ukończyłem, wiary ustrzegłem. Na ostatek odłożono dla mnie wieniec sprawiedliwości, który mi w owym dniu odda Pan, sprawiedliwy Sędzia, a nie tylko mnie, ale i wszystkim, którzy umiłowali pojawienie się Jego" (2 Tm 4, 7-8)

23 Jan Paweł II, Przemówienie na konferencji „Kościół a ludzie starsi”, Watykan 1998. 


\section{Summary}

\section{"Do not cast me away when I am old". The need for a profiled gospel procla- mation to seniors}

The elderly in the Church are assured of being under pastoral care. Nevertheless everyday experiences demonstrate that this part of pastoral care to seniors is usually mentioned in the first place, namely the preaching of the gospel of God is quite underdeveloped, if not neglected or even ignored. Indeed, do they not feel that in this respect as being cast away? The current article presents the problem of a special or profiled parochial gospel proclamation for people who are advanced in years. It is performed in three steps: firstly by substantiation, the need of such a proclamation on the grounds of homiletics and pastoral theology; secondly by discussion of its situation, forms and content; thirdly by defining and describing its basic theme that is life. The 'profiled' proclamation to seniors is understood here as special, regarding its forms, language and content, preaching of the gospel of God to people who are along in years. Preaching that is directed at them and having an impact on them.

Keywords: old people, pastoral care for seniors, preaching to seniors

\section{„Nie odtrącaj mnie w starości”. O potrzebie profilowanego przepowiadania dla seniorów}

Ludzie starsi w Kościele mają prawo do przepowiadania specjalnego, profilowanego, tzn. ukierunkowanego na nich, obejmującego ich swoim oddziaływaniem. Słowo Boże powinno być głoszone wszystkim ludziom w każdym czasie, w każdej sytuacji, na każdym etapie ich życia. Jeśli zatem widzimy potrzebę profilowanego przepowiadania do dzieci, do młodzieży czy do dorosłych, to nie możemy nie zauważać jej w odniesieniu do seniorów. Konieczność taką tłumaczą też względy duszpasterskie. Według nauczania Kościoła duszpasterze powinni pomóc osobom starym realizować swoje powołanie w Kościele i świecie, tak aby pojmowali swoją starość jako naturalny etap życia, jako czas wartościowy, który należy i można przeżywać w postawie zaufania Bogu, a także - jeśli to możliwe - zaangażowania dla wspólnoty. Specjalne kaznodziejstwo dla seniorów stanowi jeden z istotnych przejawów tej troski. Można je realizować, posługując się albo tradycyjnymi i sprawdzonymi formami przepowiadania, takimi jak homilie, kazania, nauki rekolekcyjne czy katechezy, albo ostrożnie wprowadzając nowe - np. homilie dialogowane czy świadectwa. Ważne jest przy tym, aby kaznodzieje zadbali o odpowiedni język przekazu ewangelicznego, adekwatny do sytuacji, mentalności, doświadczeń i problemów seniorów. Podstawowym motywem przepowiadania dla ludzi starych, tych, których życie doczesne dobiega kresu, powinno być życie, życie silniejsze niż śmierć.

Słowa kluczowe: ludzie starzy, duszpasterstwo seniorów, przepowiadanie dla seniorów 


\section{ks. Adam Kalbarczyk}

\section{Bibliografia}

Altenarbeit in der Diözese Rottenburg-Stuttgart. Materialdienst 29. Handreichungen für die Seelsorge, Rottenburg a. N. 1991.

Ceglarek R., Katecheza dla osób starszych, „Ateneum Kapłańskie” 1 (2011) t. 157, s. 61-72.

Jan Paweł II, Przemówienie na konferencji „Kościół a ludzie starsi”, Watykan 1998.

Kalbarczyk A., Homilia-najwyższa forma przepowiadania w Kościele, [w:] Msza Święta-rozumieć, aby lepiej uczestniczyć. Wykład liturgii Mszy, red. J. Hadalski, Poznań 2013, s. 233-238.

Lewek A., Współczesna odnowa kaznodziejstwa. Zarys homiletyki ogólnej, z. 2, Warszawa 1980.

Müller J., Pastoraltheologie. Ein Handbuch für Studium und Seelsorge, Graz-WienKöln 1993.

Ostrowski J., Przygoda W., Seniorów duszpasterstwo, [w:] Leksykon teologii pastoralnej, red. R. Kamiński, Lublin 2006, s. 789-793.

Pawłowska J., Nie odtrącaj mnie w starości. Poradnik dla osób opiekujących się ludźmi w podeszłym wieku, Poznań 2002.

Przygoda W., Starych duszpasterstwo, [w:] Encyklopedia katolicka, t. 18, red. E. Gigilewicz, Lublin 2013, kol. 868-870.

Przygoda W., Formacja apostolska ludzi w podeszłym wieku, „Perspectiva” 1 (2009), s. $170-184$.

Synod Biskupów XII Zwyczajne Zgromadzenie Ogólne Synodu Biskupów. Słowo Boże w życiu i misji Kościoła, Lineamenta (25.03.2007).

Zulehner P. M., Pastoraltheologie. Übergänge. Pastoral zu den Lebenswenden, t. 3, Düsseldorf 1990.

Zulehner P. M., Wie Musik zur Trauer ist eine Rede zur falschen Zeit. Wider den kirchlichen Wort-Durchfall, Ostfildern 1998. 